BMJ Paediatrics Open

\title{
Clinical manifestations and outcome in children with COVID-19 infection in Abu Dhabi: a retrospective single- centre study
}

\author{
Bushra Alattas (D) , ${ }^{1}$ Amer Azaz (D) , ${ }^{2}$ David Rawat (D) , ${ }^{2}$ Mohamad Miqdady (D) , \\ Rana Bitar (1) ${ }^{2}$
}

To cite: Alattas B, Azaz A, Rawat $\mathrm{D}$, et al. Clinical manifestations and outcome in children with COVID-19 infection in Abu Dhabi: a retrospective single-centre study. BMJ Paediatrics Open 2021;5:e001219. doi:10.1136/ bmjpo-2021-001219

Received 5 July 2021 Accepted 3 November 2021

A) Check for updates

\section{(C) Author(s) (or their} employer(s)) 2022. Re-use permitted under CC BY-NC. No commercial re-use. See rights and permissions. Published by BMJ.

${ }^{1}$ General Paediatric Department, Sheikh Khalifa Medical City, Abudhabi, UAE

${ }^{2}$ Pediatric Gastroenterology Department, Sheikh Khalifa Medical City, Abu Dhabi, UAE

\section{Correspondence to} Dr Bushra Alattas; Balattas@ seha.ae

\section{ABSTRACT}

We conducted a retrospective cohort review of 180 patients aged 0-18 years with positive COVID-19 nasal PCR swab admitted to the only designated paediatric COVID-19 hospital in Abu Dhabi from 1 March to 1 June 2020. 60 (33\%) patients were asymptomatic, 117 (65\%) patients had mild or moderate symptoms and 3 patients required intensive care with no mortality reported. Symptoms at presentation were fever in 84 patients, cough in 62 patients and gastrointestinal symptoms in 48 patients.

SARS-CoV-2 was the causal disease in a series of cases with severe pneumonia initially reported in Wuhan, China, ${ }^{1}$ declared as COVID-19 by the WHO. Only $2.1 \%-5 \%$ of infected patients were children ${ }^{2}$ and they typically presented with respiratory or febrile illness; however, gastrointestinal (GI) symptoms have also been recognised as presenting symptoms. The overwhelming majority of paediatric cases (over 90\%) demonstrate asymptomatic, mild or moderate disease.

The United Arab Emirates (UAE) adopted an extensive screening and contact tracing policy performing PCR nasal swab tests of 2850 per 100 000 population per day ${ }^{3}$ thereby enabling an accurate representation of paediatric COVID-19 infection. Our aim was to review paediatric COVID-19 with respect to presenting symptoms and outcomes in the UAE.

A retrospective electronic medical file review of all patients aged $0-18$ years with a positive COVID-19 PCR via nasal swab attending the only designated paediatric COVID-19 hospital in Abu Dhabi City, Sheikh Khalifa Medical City (SKMC), from 1 March to 1 June 2020 was conducted. During the months of March and April, all positive COVID-19 PCR paediatric patients were admitted to SKMC. However, during May some asymptomatic children with mild disease were quarantined in designated COVID-19 isolation hotels.
Patients were discharged from hospital if they were clinically stable and had two negative COVID-19 PCR tests within 48 hours.

Data collected included patient demographics, length of hospital stay, medical background, presenting symptoms, disease severity and patient outcome. The symptoms reviewed were fever, cough, abdominal pain, diarrhoea and vomiting. The severity of COVID-19 was defined based on clinical features, laboratory testing and chest X-ray imaging, including asymptomatic infection, mild, moderate and severe cases:

1. Asymptomatic infection: no clinical symptoms and signs.

2. Mild: symptoms of viral illness or upper respiratory tract infection such as fever, cough, diarrhoea and sore throat. Physical examination could show congestion of the pharynx and no auscultatory abnormalities.

3. Moderate: signs or symptoms of pneumonia with or without oxygen requirement but no respiratory failure.

4. Severe: patient requires ventilatory support or develops single or multiorgan failure.

Categorical variables are presented as frequency and percentage, while numerical variables are presented as mean $\pm \mathrm{SD}$ and or median (centile) with range.

Overall, 180 children were identified. Overall, 52 patients had comorbid medical diseases. All patients apart from five were admitted, with median duration of hospital stay of 3 days (range: 0-60 days) (table 1). Fever was seen in 84 patients and cough was seen in 62 patients. However, 48 patients presented with GI symptoms. Diarrhoea was the most common GI symptom (table 2). Eight patients presented with only GI symptoms. Overall, 117 patients had mild or moderate symptoms, 60 patients were asymptomatic and 3 patients were severe and required intensive care. Two patients required 


\begin{tabular}{|c|c|c|}
\hline & Category & $\mathrm{N}(\%)$ \\
\hline \multirow[t]{2}{*}{ Gender $(\mathrm{N}=180)$} & Male & $92(51 \%)$ \\
\hline & Female & $88(49 \%)$ \\
\hline Age (years) & Median, range & $4(0.01-17)$ \\
\hline \multirow[t]{5}{*}{ Age category } & Infant (0-12 months) & $41(23 \%)$ \\
\hline & Toddler (13-24 months) & $27(15 \%)$ \\
\hline & Preschool (3-5years) & $36(20 \%)$ \\
\hline & School aged (6-12 years) & $54(30 \%)$ \\
\hline & Adolescent (13-19years) & $22(12 \%)$ \\
\hline \multirow[t]{5}{*}{$\begin{array}{l}\text { Underlying medical } \\
\text { disease }(\mathrm{N}=52)\end{array}$} & $\begin{array}{l}\text { Bronchial asthma/chronic airway } \\
\text { disease }\end{array}$ & 20 \\
\hline & $\begin{array}{l}\text { Immunodeficiency, } \\
\text { immunesupression or } \\
\text { chemotherapy }\end{array}$ & 14 \\
\hline & Complex neurologic disease & 7 \\
\hline & Congenital heart disease & 6 \\
\hline & Other disorders & 5 \\
\hline
\end{tabular}

positive pressure ventilation and one patient required highflow nasal cannula $15 \mathrm{~L} / \mathrm{min}$. The patients requiring intensive care support included a 4-year-old patient with Niemann pick type $\mathrm{C}$ disease with interstitial lung disease, a 6-year-old patient with cerebral palsy who had a tracheostomy and a 10-year-old patient with autistic spectrum disorder with MI Body Mass Index of $33 \mathrm{~kg} / \mathrm{m}^{2}$. All children were discharged and no deaths reported.

Although children with COVID-19 disease typically present with respiratory illness, GI symptoms can also occur. Paediatric patients appeared to have more GI symptoms $(24.8 \%)$ when compared with adults $(16.7 \%) .{ }^{4}$ Our findings were similar, in that $27 \%$ of patients had GI symptoms.

Children with COVID-19 display a mild phenotype of disease compared with adults and $90 \%-98 \%$ of children are asymptomatic or have mild or moderate disease. ${ }^{45}$

This preliminary examination of characteristics of COVID-19 disease among children suggest that children do not always have fever or cough symptoms and GI symptoms need to be considered as part of the screening assessment in children. Our data support favourable clinical course and outcome of COVID-19 infection in children.

\begin{tabular}{ll}
\hline Table 2 & \multicolumn{1}{l}{ Length of stay and presenting symptoms } \\
\hline Length of stay (median, range) & $\mathbf{3}$ days (0.0-60.0) \\
\hline Clinical symptom* & $\mathbf{N}(\%)$ \\
\hline Fever & $84(47 \%)$ \\
Cough & $62(34 \%)$ \\
\hline Diarrhoea & $32(18 \%)$ \\
Vomiting/nausea & $20(11 \%)$ \\
\hline Abdominal pain & $17(9 \%)$ \\
\hline
\end{tabular}

${ }^{*}$ A patient may have more than one symptom.

\section{PATIENT AND PUBLIC INVOLVEMENT STATEMENT}

- How was the development of the research question and outcome measures informed by patients' priorities, experience and preferences? This is a retrospective case note review and therefore the patients were not informed of the research question and outcome measures.

- How did you involve patients in the design of this study? Patients were not involved in the design of the study mainly because the study was a retrospective study.

- Were patients involved in the recruitment to and conduct of the study? Patients were not involved in the recruitment to and conduct for the study.

- How will the results be disseminated to study participants? The results will not be disseminated to the study participants.

- For randomised controlled trials, was the burden of the intervention assessed by patients themselves? This is not a randomised controlled trial.

Correction notice This article has been corrected since it has been first published. Name of the author Mohamad Miqdady has been corrected.

Contributors RB was a research supervisor and was responsible for conception and design of the work and drafting analysis. BA designed the study and was responsible for data collection, data analysis and drafting of the article. AA, DR and MM were responsible for drafting the article and critical revision of the article.

Funding The authors have not declared a specific grant for this research from any funding agency in the public, commercial or not-for-profit sectors.

Competing interests None declared.

Patient and public involvement Patients and/or the public were not involved in the design, or conduct, or reporting, or dissemination plans of this research.

Patient consent for publication Not applicable.

Ethics approval The study was approved by the Institutional Review Board Committee for COVID-19 research in the Department of Health, Abu Dhabi.

Provenance and peer review Not commissioned; externally peer reviewed.

Open access This is an open access article distributed in accordance with the Creative Commons Attribution Non Commercial (CC BY-NC 4.0) license, which permits others to distribute, remix, adapt, build upon this work non-commercially, and license their derivative works on different terms, provided the original work is properly cited, appropriate credit is given, any changes made indicated, and the use is non-commercial. See: http://creativecommons.org/licenses/by-nc/4.0/.

\section{ORCID iDs}

Bushra Alattas http://orcid.org/0000-0002-5571-5295

Amer Azaz http://orcid.org/0000-0003-2303-0846

David Rawat http://orcid.org/0000-0003-17888758

Mohamad Miqdady http://orcid.org/0000-0001-9089-9424

Rana Bitar http://orcid.org/0000-0002-2852-7707

\section{REFERENCES}

1 Li Q, Guan X, Wu P, et al. Early transmission dynamics in Wuhan, China, of novel coronavirus-infected pneumonia. N Engl J Med 2020;382:1199-207.

2 Saux NL. Current epidemiology and guidance for COVID-19 caused by SARS-Co V-2 virus in children. Canadian Pediatric society, 2020.

3 Ministry of Cabinet affairs, UAE. Federal competitiveness and statistics authority, 2020.

4 Lu X, Zhang L, Du H, et al. SARS-CoV-2 infection in children. N Engl J Med 2020;382:1663-5.

5 Chang T-H, Wu J-L, Chang L-Y. Clinical characteristics and diagnostic challenges of pediatric COVID-19: a systematic review and metaanalysis. J Formos Med Assoc 2020;119:982-9. 